\title{
DIFFERENCES BETWEEN PRIMARY AND SECONDARY SCHOOL PRINCIPALS' ROLE, THEIR ROLE AND POTENTIAL PRINCIPALS' PERCEPTIONS
}

\section{Zeljko Burcar}

ES F. K. Frankopana, Zagreb, Croatia

CMESTE

JEL Category: 100, 12, 121

\begin{abstract}
The aim of this research is to identify differences between primary and secondary school principals' roles and the differences between the roles that principals perform and potential principals perceive. Under the term "potential principals" the author considered teachers and expert associates which have legal conditions to access the contest for principal and have the opportunity, to be chosen for principal function. The used questionnaire, constructed by the author, contained 192 variables about principals' tasks, and 10 questions provided data about the respondents' surroundings. Sample $N=119$ principals ( $N=83$ elementary, $N=36$ secondary, presents $10 \%$ of principals' population in Croatia), and $N=120$ potential principals, provided answers in six categories of the Likert scale; from completely disagree to completely agree. Results confirm that the principals perform more duties that the law requires of them. Statistically, significant differences between principals' jobs in elementary and secondary school exist in six variables. Differences between teachers' perception and jobs principals do exist in $39 \%$ of examined variables.
\end{abstract}

Keywords: Education system, education analyses, school management, leadership, principal's role

\section{INTRODUCTION}

During the last fifteen years, there are plenty of researches and articles in both, profit and nonprofit sector dealing with the managers and leaders roles. In this research, we would like to exam the role of the principal through its realization and the work they do. The idea is based

Address of the author:

Zeljko Burcar

拝=” zeljko.burcar@zg.t-com.hr on the premise that the role is realized through acting. Through acting, tasks were realized. By realizing tasks, goals were achieved. Achieving goals guide to the role realization (Burcar, 2013).

This research examines the role of the school principal within the context of modern-day schooling. The term role translated in Croatian literature is ambiguously defined. The term role "uloga" includes the role and function (EnglishCroatian dictionary, Filipovic, 1970, p. 846), "The term 'role' usually refers to the function performed by someone" (Zvonarevic, 1978, p. 276, from 
Stanicic, 2006), "The 'role' means specific expectations of other people from the person who carries a particular function" (Bahtijarevic-Šiber, \& Sikavica, 2001, p. 616). It may be concluded that the term 'role' in the Croatian language presents synonymous with the function. The function explanation, to which we adhere, gives Antic (2000, p. 297): To principal as "the first person in the school," is entrusted function of the "main commander" whose work in school can be understood as the state representative, governed under the delegated functions. Assigned functions include:
a. planning and programming,
b. managing,
c. keeping,
d. organizing,
e. routing,
f. monitoring,
g. controlling,
h. evaluating and
i. a circle of administrative and financial activities called the administrative jobs.

We agreed that the term role could be defined as behaving expected from the person that possess respective position in the group (Pennington, 2001 , p. 279). The principal's role is realized in the organization we named school. At the same time, the organization is a group in which unequal distribution of social power and responsibility exists, as Zvonarevic (1981, p. 323) extracted. Principals show attitudes about their managerial and leadership roles (Burcar, 2013). Their roles cover four areas: status, organizing, leading and decision-making (Burcar, 2014). Principals are involved in the following processes: planning, decision-making, organizing, coordinating, communicating, impact and evaluation (Burcar, 2013). The managerial role of the principal derives from the exercising governance in schools, "the management is realized in four specific groups of activities: planning, organizing, leading and evaluating" (Stanicic at.al. 2002, p. 149), but also from the fact that the principal performs the parts of the administrative processes and the processes prescribed by legislation. From the analysis of the historical continuum may be concluded that the principal is no longer a manager and his role is no longer the dominant organizational, but also transforms to the role of instructional leader, (Bovalino, 2007, p. 16.). Some authors advocate a different opinion and explain that the role of principals in recent years increasingly transforms from educational leaders to business managers (Burcar, 2010), which we accept with caution.

\section{METODOLOGHY}

The goal of this research is focused on the description of the role of the principal through its job analysis. The role of the principal in this research has been examined through the job analysis, as well as the job estimation of the potential principals. The goal of the research was operationalized through the following tasks: a) Principals' jobs in the school have been examined through the empirical research. b) Potential principals' attitudes about the principals' jobs have been tested through the empirical research. c) Differences between secondary and primary school principals' jobs have been tested. d) Differences between principals' jobs and potential principals' attitudes about their jobs have been tested.

\subsection{Sampling and sample}

The first sample is intentional and consists of 119 principals, of which 83 elementary and 36 secondary school principals $(10 \%$ of principals population in Croatia). The sample is stratified for the purpose of the research. The second sample consists of 120 potential principals: teachers and expert associates. Potential principals are class teachers, subject teachers, and expert associates which have legal conditions to access the contest for the principal. As well as they have the opportunity to be chosen for principal function, because they have a degree that allows them to work in the school as teachers, and have at least eight years of working experience in the school institutions, what are the legal requirements to become a principal? The tasks of class teachers can perform people ended:

a. Integrated undergraduate and graduate programs for teachers,

b. graduate university studies for teachers,

c. professional four-year studies for teachers in order to acquire 240 credits,

d. four-year undergraduate professional study which is acquired a university degree in accordance with previous regulations. 
Subject teachers' tasks can perform a person who has completed:

a. the proper type of graduate study,

b. the proper type of integrated undergraduate and graduate study,

c. the appropriate type of specialist professional graduate study,

d. the appropriate type of undergraduate university degree or professional study with a minimum of 180 credits and has pedagogicalpsychological didactic and methodical education with 60 ECTS points in specific situations.

According to the Consolidated Law on Education from 2012 workers caught in work and employed according to previous laws with lower educational level can continue to perform their job, but they can not become a principal.

Booth samples present skillful, educated and experienced persons, appropriate for this research as representatives of the population and useful generalization. Booth samples fulfill questionnaire with their own will during the national professional conference they participate.

\subsection{Methods}

For this research, basic statistics has been used, as well as nonparametric testing. Mean (M) as a measure of central tendency and standard deviation (SD) as a measure of distortion from mean, minimum and maximum of results have been used as well as median and mode. Correlations between variables have been computed to determine relations between variables. Secondly, the Kolmogorov-Smirnov normality test has been carried out for distribution type. The differences between groups have been tested. The level of relations between tested variables and the level of differences between the two compared samples have been confirmed after the statistical significance of correlations or differences has been proven.

\subsection{Instrument - questionnaire}

For the purpose of this research, for data collection questionnaire designed by Burcar (2010) has been used consisting of 192 variables, which describes different jobs principals perform. Examples:

a) I am reading daily papers. b) I am informing school board.

c) I am planning staff.

d) I am organizing staff,

e) I am reporting school board, etc.).

The questionnaire consists of 8 subscales:

a. Information collector and divider,

b. Communicator,

c. Strategist and Planner,

d. Executive manager, administrator, and organizer,

e. Instructional leader and educator,

f. Evaluator,

g. Student,

h. Binder with the community.

The questionnaire also contained 10 questions, which provided data about the respondent and the respondent's school as well (mission, motto, working hours a day/week, education, gender etc.). The respondents provided answers in line with six categories of the Likert scale: (1) Completely disagree, (2) Strongly disagree, (3) Disagree, (4) Agree, (5) Strongly agree, (6) Completely agree, (Bell, p. 165 in Coleman \& Briggs, ed. 2003).

\section{RESULTS AND DISCUSSION}

The results for booth samples shows nonparametric distributions of variables what is expected, because of questionnaire constructed for this research, based on qualitative values and because of fact that results show categorized numerical values on the ordinary scale. Regarding this facts, nonparametric statistical tests have been used as well. The correlations were tested with the Spearman Rank Order Correlations. The differences were tested with Kolmogorov-Smirnov two sample tests.

The sample in this research (67 male, 52 female) which present principals included in this research, work in the schools with 511 pupils in average. Their schools work in 1-4 shifts. Principals generally have gained university diploma $(89.92 \%)$. On the other hand, a sample that presents potential principals ( 22 male, 88 female) work in the schools with 564 pupils in average. Their schools work in 1-3 shifts. Potential principals generally have higher, 2 years university degree $(22.50 \%)$ or high, 4 years university degree $(67.50 \%)$ (Tables 1 and 2 ). 
Table 1. Number of working shifts

\begin{tabular}{|c|c|c|c|c|}
\hline \multirow{2}{*}{$\begin{array}{c}\text { Number } \\
\text { of shifts }\end{array}$} & \multicolumn{2}{|c|}{ Principals $(\mathrm{n}=119)$} & \multicolumn{2}{|c|}{$\begin{array}{c}\text { Potential principals } \\
(\mathrm{n}=120)\end{array}$} \\
\cline { 2 - 5 } & $\mathrm{N}$ & $\% \mathrm{~N}$ & $\mathrm{~N}$ & $\% \mathrm{~N}$ \\
\hline 1 & 31 & 26.05 & 19 & 15.83 \\
\hline 2 & 82 & 68.91 & 80 & 66.67 \\
\hline 3 & 4 & 3.36 & 2 & 167 \\
\hline 4 & 2 & 1.68 & & \\
\hline
\end{tabular}

$82.35 \%$ (98) of all principals reported that their schools do not have a mission statement, $85.54 \%$ (71) elementary school principals and $75 \%$ (27) secondary school principals. At the same time, they reported that their schools have a motto $61.34 \%$ (73) of all principals, and $60.24 \%$ (50) elementary school principals and $63.89 \%$ (23) secondary school principals. This seems unusual because motto is usually derived from clearly defined vision and mission, and it is questionable do they understand the purpose of the mission statement in contemporary management practice.

\section{Table 2. Educational level}

\begin{tabular}{|c|c|c|c|c|}
\hline & \multicolumn{2}{|c|}{$\begin{array}{c}\text { Principals } \\
(\mathrm{n}=119)\end{array}$} & \multicolumn{2}{c|}{$\begin{array}{c}\text { Potential } \\
\text { principals } \\
(\mathrm{n}=120)\end{array}$} \\
\cline { 2 - 5 } Education level & $\mathrm{N}$ & $\% \mathrm{~N}$ & $\mathrm{~N}$ & $\% \mathrm{~N}$ \\
\hline $\begin{array}{c}\text { Middle level - middle } \\
\text { school for teacher (older } \\
\text { teachers) - ISCED 3 }\end{array}$ & & & & \\
\hline $\begin{array}{c}\text { Higher level - 2 years' } \\
\text { education for teacher } \\
\text { (ISCED 5) }\end{array}$ & 9 & 7.56 & 27 & 22.50 \\
\hline $\begin{array}{c}\text { High level - 4 years, } \\
\text { 3+2 years or 5 years } \\
\text { integrated university } \\
\text { education (ISCED 5) }\end{array}$ & 107 & 89.92 & 81 & 67.50 \\
\hline $\begin{array}{c}\text { Scientific level (Master } \\
\text { of science, or PhD) - } \\
\text { ISCED 6 }\end{array}$ & 3 & 2.52 & 4 & 3.33 \\
\hline
\end{tabular}

Cronbach Alpha for a set of items in questionnaire tested on principals is 0.98 with internal consistency for variables between 0.21 to 0.68 . For the set of items in questionnaire tested on potential principals' internal consistency for variables is between 0.25 to 0.84 with Cronbach Alpha (0.99). Cronbach Alpha for items in the subscales tested on the principals varies between 0.85 and 0.92 (Table 3), explains the high level of reliability for each subscale of the questionnaire and also for the entire questionnaire.
Table 3. Subscale analyses

\begin{tabular}{|c|c|c|c|c|c|}
\hline Subscales & 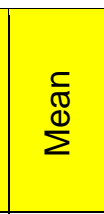 & 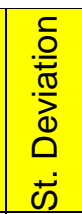 & 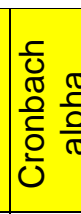 & $\begin{array}{l}\frac{\pi}{\frac{\pi}{0}} \\
\frac{0}{\sigma} \\
\frac{0}{\sigma} \\
\frac{\pi}{0} \\
\frac{\pi}{\omega}\end{array}$ & 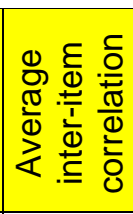 \\
\hline $\begin{array}{l}\text { Information } \\
\text { collector and divider }\end{array}$ & 71.75 & 8.24 & 0.88 & 0.88 & 0.35 \\
\hline Communicator & 62.36 & 6.68 & 0.85 & 0.85 & 0.34 \\
\hline $\begin{array}{l}\text { Strategist and } \\
\text { planner }\end{array}$ & 76.60 & 8.04 & 0.85 & 0.86 & 0.30 \\
\hline $\begin{array}{l}\text { Executive manager, } \\
\text { administrator, and } \\
\text { organizer }\end{array}$ & 76.06 & 8.03 & 0.85 & 0.86 & 0.30 \\
\hline $\begin{array}{l}\text { Instructional leader } \\
\text { and educator }\end{array}$ & 76.06 & 8.03 & 0.85 & 0.86 & 0.30 \\
\hline Evaluator & 63.06 & 7.98 & 0.90 & 0.90 & 0.42 \\
\hline Student & 49.65 & 6.36 & 0.90 & 0.90 & 0.48 \\
\hline $\begin{array}{l}\text { Binder with } \\
\text { community }\end{array}$ & 40.80 & 6.58 & 0.92 & 0.92 & 0.60 \\
\hline
\end{tabular}

We can conclude that differences between jobs among principals in elementary and secondary schools exist in 6 of 192 variables (Table 4). Jobs listed in the table defers because of legislation. Secondary schools do not have an obligation for pupil's kitchen. For organizing teachers replacement secondary school principals have established expert - associates. The results guide us to the conclusion that the secondary school principals have bigger daily and weekly workload then the principals in elementary schools.

The results from KS two-sample test shown in Table 5 reveal statistically significant differences between the surveyed samples of groups (principals and potential principals) on $14.95 \%$ of all analyzed variables. Statistically significant differences on the level of significance $P<.05$, $P<.01$ and $P<.001$, was determined on $36.60 \%$ of all variables. This suggests that potential principals do not have a clear overview of jobs and obligations that principals perform. This different perception of the principals' job points to the fact, those potential principals could not perform principals' function without appropriate preparation. Furthermore, significant differences arose in the fields of informing/disseminating information's, communicating, planning, organizing, leading, administrating, evaluating, conflict solving as well as in the daily and weekly workload. 
Table 4. Differences between elementary and secondary school principals (KS two-sample test)

\begin{tabular}{|l|c|c|c|c|c|c|c|c|c|}
\hline Variable & $\begin{array}{c}\text { Max - } \\
\text { Diff. }\end{array}$ & $\begin{array}{c}\text { Max. } \\
+ \\
\text { Diff }\end{array}$ & $\boldsymbol{P}$-level & $\begin{array}{c}\mathrm{M} \\
\text { Group } \\
1\end{array}$ & $\begin{array}{c}\mathrm{M} \\
\text { Group } \\
2\end{array}$ & $\begin{array}{c}\text { SD } \\
\text { Group } \\
1\end{array}$ & $\begin{array}{c}\text { SD. } \\
\text { Group } \\
2\end{array}$ & $\begin{array}{c}\mathrm{N} \\
\text { Group } \\
1\end{array}$ & $\begin{array}{c}\mathrm{N} \\
\text { Group } \\
2\end{array}$ \\
\hline Plans meals for pupils & 0 & 0.30 & $\boldsymbol{P}=.05$ & 3.96 & 2.75 & 1.32 & 1.25 & 83 & 36 \\
\hline $\begin{array}{l}\text { Organizes teachers } \\
\text { replacement }\end{array}$ & 0 & 0.28 & $\boldsymbol{P}=.05$ & 4.40 & 3.83 & 1.05 & 0.85 & 83 & 36 \\
\hline $\begin{array}{l}\text { Organizes meals for } \\
\text { pupils }\end{array}$ & 0 & 0.32 & $\boldsymbol{P}=.05$ & 3.54 & 2.64 & 1.36 & 1.27 & 83 & 36 \\
\hline $\begin{array}{l}\text { Evaluates plan for } \\
\text { pupils meals }\end{array}$ & 0 & 0.35 & $\boldsymbol{P}<.01$ & 3.65 & 2.61 & 1.28 & 1.18 & 83 & 36 \\
\hline Work daily & -0.29 & 007 & $\boldsymbol{P}=.05$ & 8.66 & 8.97 & 131 & 1.182 & 82 & 36 \\
\hline Work weakly & -0.31 & 0.02 & $\boldsymbol{P}=.05$ & 44.99 & 47.94 & 8.13 & 7.51 & 82 & 36 \\
\hline
\end{tabular}

Group 1 elementary school principals; Group 2 secondary school principals; N Group 1 \& 2 number of cases in the group; M Group 1 \& 2 arithmetic means in the group; Max - Diff. negative difference; Max + Diff. positive difference; SD Group $1 \& 2$ standard deviations in the group; $\boldsymbol{P}$-level statistical significant level

Table 5. Differences between principals and potential principals (KS two-sample test)

\begin{tabular}{|c|c|c|c|c|c|c|c|c|c|}
\hline Variable & $\begin{array}{c}\text { Max }- \\
\text { Diff. }\end{array}$ & $\begin{array}{c}\text { Max.+ } \\
\text { Diff }\end{array}$ & $P$-level & $\begin{array}{c}M \\
\text { Gr. } 1 \\
\end{array}$ & $\begin{array}{c}\mathrm{M} \\
\text { Gr. } 2 \\
\end{array}$ & $\begin{array}{c}\text { SD } \\
\text { Gr. } 1 \\
\end{array}$ & \begin{tabular}{c|}
$\mathrm{SD}$ \\
$\mathrm{Gr} .2$ \\
\end{tabular} & $\begin{array}{c}N \\
\text { Gr. } 1\end{array}$ & $\begin{array}{c}N \\
\text { Gr. } 2\end{array}$ \\
\hline Read regular mail & -0.01 & 0.28 & $P<.001$ & 5.44 & 4.89 & 0.81 & 0.96 & 119 & 119 \\
\hline Write e-mails. mails and submissions & 0.00 & 0.33 & $P<.001$ & 5.03 & 4.36 & 1.05 & 1.08 & 119 & 119 \\
\hline Speak with parents live & 0.00 & 0.30 & $P<.001$ & 5.24 & 4.70 & 0.85 & 1.13 & 119 & 120 \\
\hline Speaks with local representatives & -0.02 & 0.30 & $P<.001$ & 4.91 & 4.47 & 0.98 & 1.00 & 119 & 120 \\
\hline Speaks with secretary and bookkeeper & 0.00 & 0.26 & $P<.001$ & 5.68 & 5.18 & 0.69 & 0.94 & 119 & 120 \\
\hline Speaks with pupils & 0.00 & 0.26 & $P<.001$ & 5.35 & 4.78 & 0.84 & 1.12 & 119 & 120 \\
\hline Plans school year plan & 0.00 & 0.32 & $P<.001$ & 5.50 & 4.83 & 0.76 & 1.11 & 119 & 120 \\
\hline Plans classes & 0.00 & 0.37 & $P<.001$ & 5.30 & 4.50 & 0.91 & 1.11 & 119 & 119 \\
\hline Plans projects & 0.00 & 0.29 & $P<.001$ & 4.93 & 4.33 & 0.92 & 1.21 & 119 & 119 \\
\hline Plans employees & 0.00 & 0.32 & $P<.001$ & 5.47 & 4.75 & 0.84 & 1.11 & 119 & 120 \\
\hline Organiz & 0.00 & 0.26 & $P<.001$ & 5.25 & 4.77 & 0.84 & 0.89 & 119 & 119 \\
\hline Develops staffing ana & 0.00 & 0.32 & $P<.001$ & 5.46 & 4.67 & 0.85 & 1.22 & 119 & 120 \\
\hline Provides an instructive chat with teachers & 0.00 & 0.31 & $P<.001$ & 5.03 & 4.45 & 0.90 & 0.87 & 119 & 120 \\
\hline $\begin{array}{l}\text { Provides instructive chat } \\
\text { associates }\end{array}$ & 0.00 & 0.30 & $P<.001$ & 5.20 & 4.61 & 0.90 & 0.91 & 119 & 120 \\
\hline ons for employees & 0.00 & 0.35 & $P<.001$ & 4.57 & 3.83 & 0.95 & 1.22 & 119 & 120 \\
\hline $\begin{array}{l}\text { Teaches employees the pedagogical and } \\
\text { psychological principles and methods of } \\
\text { evaluation }\end{array}$ & 0.00 & 0.28 & $P<.001$ & 4.46 & 3.82 & 0.90 & 1.17 & 119 & 120 \\
\hline $\begin{array}{l}\text { Teaches } \\
\text { techniqu }\end{array}$ & 0.00 & 0.47 & $P<.001$ & 4.49 & 3.56 & 0.81 & 1.24 & 119 & 120 \\
\hline Chair the me & 0.00 & 0.27 & $P<.001$ & 5.30 & 4.72 & 0.88 & 0.98 & 119 & 120 \\
\hline Makes $r$ & 0.00 & 0.26 & $P<.001$ & 4.01 & 3.29 & 1.18 & 1.42 & 119 & 120 \\
\hline Solve conflicts between employees & 0.00 & 0.32 & $P<.001$ & 5.04 & 4.28 & 0.85 & 1.17 & 119 & 120 \\
\hline $\begin{array}{l}\text { Organizes and participates in joint meeting } \\
\text { with employees }\end{array}$ & 0.00 & 0.26 & $P<.001$ & 5.02 & 4.63 & 0.88 & 1.04 & 118 & 120 \\
\hline Create annual school plan & 0.00 & 0.36 & $P<.001$ & 5.14 & 4.41 & 0.84 & 1.07 & 119 & 120 \\
\hline Creates reports. charts and analyzes & -0.01 & 0.30 & $P<.001$ & 4.34 & 3.81 & 0.92 & 1.34 & 119 & 119 \\
\hline Create working loads and responsibility & 0.00 & 0.26 & $P<.001$ & 4.91 & 4.41 & 1.17 & 1.13 & 119 & 120 \\
\hline Create employees educational plans & 0.00 & 0.30 & $P<.001$ & 4.24 & 3.53 & 0.88 & 1.32 & 119 & 120 \\
\hline Analyzes personal notes & 0.00 & 0.25 & $P<.001$ & 4.70 & 4.12 & 0.96 & 1.13 & 119 & 120 \\
\hline
\end{tabular}


Burcar Z. Primary and secondary school principals' role

MEST Journal Vol. 5 No. 2 pp. 7-14

\begin{tabular}{|l|c|c|c|c|c|c|c|c|c|}
\hline Variable & Max & Max.+ & & M & M & SD & SD & N & N \\
& Diff. & Diff & $\boldsymbol{P}$-level & Gr. 1 & Gr. 2 & Gr. 1 & Gr. 2 & Gr. 1 & Gr. 2 \\
\hline Enhance interpersonal relations & 0.00 & 0.27 & $\boldsymbol{P}<.001$ & 5.32 & 4.70 & 0.79 & 1.29 & 119 & 119 \\
\hline Works daily & 0.00 & 0.28 & $\boldsymbol{P}<.001$ & 8.75 & 7.81 & 1.27 & 1.74 & 118 & 111 \\
\hline Works weekly & -0.01 & 0.35 & $\boldsymbol{P}<.001$ & 45.89 & 39.75 & 8.03 & 10.02 & 118 & 108 \\
\hline
\end{tabular}

Group 1 principals; Group 2 potential principals (teachers and expert associates); N Gr. 1 \& 2 number of cases in the group; M Gr. $1 \& 2$ arithmetic means in the group; Max - Diff. negative difference; Max + Diff. positive difference; SD Gr. 1 \& 2 standard deviation in the group; $\boldsymbol{P}$-level statistical significant level

Table 6. Workload differences between principals and potential principals

\begin{tabular}{|c|c|c|c|c|c|c|c|}
\hline \multicolumn{3}{|c|}{ Principals } & \multicolumn{3}{c|}{ Potential principals } \\
\hline $\begin{array}{c}\text { Working } \\
\text { hours/day }\end{array}$ & $\begin{array}{c}\text { Working } \\
\text { hours/week }\end{array}$ & \multicolumn{2}{c|}{$\begin{array}{c}\text { Working } \\
\text { hours/day }\end{array}$} & \multicolumn{2}{c|}{$\begin{array}{c}\text { Working } \\
\text { hours/week }\end{array}$} \\
\hline M & 8.75 & M & 45.89 & M & 7.81 & M & 39.75 \\
\hline SD & 1.27 & SD & 8.03 & SD & 1.74 & SD & 10.02 \\
\hline
\end{tabular}

According to the results shown in Table 6, an average principal working day $(M=8.75$ hours/day), and working week (M=45.89 hour/week) are longer than potential principals estimate $\quad(M=7.81 \quad$ hours/day, $M=39.75$ hours/week). This result leads us to the conclusion that potential principals did not have a clear and real picture about principals' workload. It seems that potential principals do no participate in school organizational processes what is close to conclusion given from Burcar $(2015$, p. 43$)$ that in prognosis of principals informational jobs the biggest influence has variable: teachers' weekly workload, from what it can be concluded that teacher who works longer have better overview onto principals' communicational jobs. Furthermore, that conclusion has been confirmed by Kolmogorov-Smirnov two-sample test results in workload variables shown in Table 4.

\section{CONCLUSIONS}

The results of this research support a model of the principal's role in the Croatian educational system developed from Burcar (2013). A high percentage of the principals from booth groups reported that their school does not have a mission statement what is in a collision with the conclusion that their school had a motto. The principals' average working day is longer than potential principals' estimate. The results of the research lead to the conclusion that differences between the principals' jobs in elementary and secondary schools exist in 6 variables. The results point to the fact that significant difference between the groups of principals and potential principals exist in $36.60 \%$ of all variables. At the level of conclusion (99.999\%) difference has been observed in $15 \%$ of all analyzed variables. It can be concluded that potential principals do not have a clear overview of jobs and obligations that principals perform. This different perception point to the fact, those potential principals could not perform principals' function without appropriate preparation, what is in line with findings from Burcar (2007). Furthermore, significant differences arisen in the important areas principals covers: informing / disseminating information, communicating, planning, organizing, leading, administrating, evaluating, conflict solving and in the daily and weekly workload as well, which are the pillars of educational changes and adaptation or educational design, explained by Burcar (2016).

The main value of this research is focused on the fact that research is based on the principal's job, or to the answer to the question: what principal do? Firstly, this knowledge and results from this research can help legislation creators to define curricula for the principal's additional learning system. Secondly, findings related to the differences between elementary and secondary school principals' job can be very helpful for combining groups of principals during additional training and education. Furthermore, the conclusions of this research can be helpful for understanding, that competent teacher could not be automatically the best option for the principal's function without additional and focused education, and appropriate preparation as well, because teachers' and principals' job differs in many components. 


\section{WORKS CITED}

Antic, S. (2000). Dictionary of contemporary education. (Croatian: Rijecnik suvremenog obrazovanja. Zagreb: Hrvatski pedagosko-knjizevni zbor.

Bahtijarevic-Šiber, F., \& Sikavica, P. (2001). The management lexicon. (Croatian: Leksikon menadzmenta. Zagreb: Masmedia.

Bell, J. (2003). Questionnaires: in Coleman, M., \& Briggs, A.R.J. (Ed), Research Methods in Educational Leadership and Management (pp. 150-171). London: University of London.

Bovalino, J.W. (2007). The Role of the Principal in the Change Process: The Road to Inclusion. (Dissertation, University of Pittsburg). University of Pittsburg.

Burcar, Z. (2007). The impact of some system elements and some processes onto elementary school quality. (Croatian: Utjecaj nekih elementa sustava i nekih procesa na kvalitetu osnovne skole). Andragoski glasnik. 11 (1/2007), p. 23-30.

Burcar, Z. (2010). The Role of the Principal and its Realization in Croatian Educational System (Croatian: Uloga ravnatelja i njezino ostvarivanje u hrvatskom skolstvu). (Dissertation, Sveuciliste u Rijeci). Rijeka: Filozofski fakultet Sveucilista u Rijeci.

Burcar, Z. (2013). The prediction of attitudes toward principals managerial and leadership jobs through the number of student, shifts and weekly time work analyses. (Croatian: Predikcija stavova o menadzerskim i liderskim poslovima ravnatelja kroz analizu broja ucenika, broja smjena i tjednog radnog vremena ravnatelja) Magistra ladertina (1846-3606) 8 (2013), 1; 127-140

Burcar, Z. (2013). School Management and Leadership. (Croatian: Školski menadzment i liderstvo): Split: Redak d.o.o., 2013 (monograph).

Burcar, Z. (2014). Role of the Principal in Croatian Education Manager, Leader or Administrator. The European Journal of Mental Health. 9 (2014), 1; 87-96.

Burcar, Z. (2015). Relationship between Teachers' Attitudes about Principals' Communicational Jobs toward School Size, Level of Teachers' Education, Workload and Gender. International Journal for Innovation Education and Research. Vol:-3 No-10, 2015, 37-44

Burcar, Z. (2016). Theoretical Algorithm of Educational Design. Journal of Global Research in Education and Social Science. 7 (3): 127-134, 2016

Filipovic, R. (Ed). (1970). English-Croatian dictionary. (Ed) Filipovic. R. Zagreb: Zora

Pennington, D. C. (2001). Social psychology. (Croatian: Socijalna psihologija). Jastrebarsko: Naklada Slap.

Stanicic, S. (2006). Management in Education. (Croatian: Menadzment u obrazovanju). Rijeka: Osobna naklada.

Stanicic, S., Burcar, Z., Hek, A., Patajac, J., Podravec, D., Rehak, A. T., \& Riggati, Z. (2002). Managing and Leading. (Croatian: Rukovodjenje i upravljanje). In Strugar, V. (Ed.), Projekt IZVORIŠTE, The concept of changes of the educational system in the Republic of Croatia. (Croatian: Koncepcija promjena odgojno-obrazovnog sustava u Republici Hrvatskoj) (pp. 143-154). Zagreb: Ministarstvo prosvjete i sporta,.

Zvonarevic, M. (1978). from Stanicic, S. (2006). Management in education. (Croatian: Menadzment u obrazovanju). Rijeka: Vlastita naklada.

Zvonarevic, M. (1981). Social psychology. (Croatian: Socijalna psihologija). Zagreb: Školska knjiga.

Received for publication: 26.10.2016

Revision received: $\quad 24.11 .2016$

Accepted for publication: 16.01 .2017 


\section{How to cite this article?}

Style - APA Sixth Edition:

Burcar, Z. (2017, July 15). Differences between primary and secondary school principals' role, their role and potential principals' perceptions. (Z. Čekerevac, Ed.) MEST Journal, 5(2), 7-14. doi:10.12709/mest.05.05.02.02

Style - Chicago Sixteenth Edition:

Burcar, Zeljko. "Differences between primary and secondary school principals' role, their role and potential principals' perceptions." Edited by Zoran Čekerevac. MEST Journal (MESTE) 5, no. 2 (July 2017): 7-14.

Style - GOST Name Sort:

Burcar Zeljko Differences between primary and secondary school principals' role, their role and potential principals' perceptions [Journal] // MEST Journal / ed. Čekerevac Zoran. - Toronto - Belgrade : MESTE, July 15, 2017. - 2 : Vol. 5. - pp. 7-14.

Style - Harvard Anglia:

Burcar, Z., 2017. Differences between primary and secondary school principals' role, their role and potential principals' perceptions. MEST Journal, 15 July, 5(2), pp. 7-14.

Style - ISO 690 Numerical Reference:

Differences between primary and secondary school principals' role, their role and potential principals' perceptions. Burcar, Zeljko. [ed.] Zoran Čekerevac. 2, Toronto - Belgrade : MESTE, July 15, 2017, MEST Journal, Vol. 5, pp. 7-14. 